\title{
CLIL IN TOURISM STUDENTS' MULTICULTURAL COMPETENCE DEVELOPMENT
}

\author{
Inna Goncharova \\ V. I. Vernadsky Taurida National University, Ukraine \\ innagoncharova1978@gmail.com \\ Olena Lazebna \\ National Technical University of Ukraine "Igor Sikorsky Kyiv Polytechnic Institute”, Ukraine \\ o.a.lazebna@gmail.com \\ Viktoriia Kotvytska \\ National Technical University of Ukraine "Igor Sikorsky Kyiv Polytechnic Institute”, Ukraine \\ v.a.kotvytska@gmail.com
}

\begin{abstract}
The current study aims at implementation of the Content and Language Integrated Learning (CLIL) as an educational approach in tourism students' multicultural competence development. To achieve the goal, a mixed-method was chosen, which implied the use of quantitative and qualitative research methods. The quantitative method was used to process the test results of tourism students and determine the statistical significance of the results obtained during the experiment, the qualitative method was used to analyse and interpret the results. 25tourism students of V. I. Vernadsky Taurida National University took part in the experimental study in 2020 2021 academic year. According to the results, due to CLIL classes the students' theoretical knowledge and practical skills in the field of tourism, the ability to interact with representatives of other countries and cultures and to solve professional problems in the conditions of foreign language communication in the intercultural environment, have been increased. Additionally, the knowledge, skills and abilities of the tourism students; the pedagogical conditions of successful CLIL implementation; the methodological recommendations for developing the multicultural competence on the base of CLIL and the specifics of implementing CLIL in the educational process of the tourism students were defined. It was concluded that the use of CLIL in tourism students' multicultural competence development helps to diversify foreign language learning at the university level and facilitates the development of professional communicative skills.
\end{abstract}

Keywords: content and language integrated learning (CLIL); tourism students; multicultural competence.

\section{Introduction}

One of the most significant trends of the modern world and Ukrainian society is the global expansion of tourism due to the intensive development of cultural and spiritual human needs, deepening multifaceted interaction of societies, universalisation, and globalisation of economic, political, cultural and communicative ties, as well as means of communication. Frequent travelling of people to another cultural environment accelerates the processes of economic and cultural interaction, intensifies the density of intercultural communication.

To meet the contemporary requirements of the multicultural world, the competent professionals in the field of tourism have to be able to communicate in foreign languages at a level sufficient for solving communication issues, find meaningful compromises, be tolerant of other people's opinions, seek mutual understanding, cooperation, and non-conflict coexistence with representatives of different cultures. Thus, society today requires higher education to train professionals in the tourism industry and hospitality with a high level of multicultural competence.

Content and Language Integrated Learning (CLIL) as an educational approach is used for enhancing foreign language competence. CLIL is "best considered as an umbrella concept that encompasses various teaching and learning interpretations and practices" (Kao, 2020, p. 2). According to Coyle, Hood, and Marsh (2010), CLIL is "an approach which is neither language learning nor subject learning, but an amalgam of both and is linked to the processes of convergence" (p. 36). In its turn, "convergence involves the fusion of elements which may have been previously fragmented, such as subjects in the curriculum" (Coyle, Hood, and Marsh 2010, p. 36). CLIL is based on four key building blocks, known as the 4Cs - Content, Communication, Cognition, and Culture (Coyle, Holmes, and King, 2009).

The effectiveness of CLIL use in the process of professional training of teachers in Italy is proved by Aiello et al. (2017). In this line, Aguilar and Muñoz (2014) identified the benefits of using CLIL for

(C) Inna Goncharova, Olena Lazebna, Viktoriia Kotvytska. 2021. Published by Igor Sikorsky Kyiv Polytechnic Institute. This is an Open Access article distributed under the terms of the licence CC BY 4.0 
engineering students in Spain. Banegas and Beamud (2020) investigated the use of CLIL in higher education in Argentina and Spain based on a duoethnographic approach; Leshchenko, Lavrysh, and Halatsyn (2018) identified operating CLIL models and strategies at Igor Sikorsky Kyiv Polytechnic Institute and measured up functioning features of this approach by means of SWOT analysis. The focus of Bentley's (2010) study was to develop tests on the professional competence of teachers in applying CLIL. Burkart (2018) suggested a method of dialogic introspection in the process of using CLIL, Cenoz (2015) made a comparative analysis of CLIL and content-based instruction. Analysing the possibilities of using CLIL online, Kao (2020) stated that "CLIL can be a motivating force for both teachers and students, but it is important that the training in CLIL is planned in a controlled and positive manner if it is to be implemented successfully" (p. 16). Additionally, Mann and Walsh (2017) investigated the importance of reflective practices in the process of teaching English, McDougald (2015) summarised the experience and attitudes towards the methods of CLIL application by teachers in Colombia, Morton (2019) developed practical recommendations for the use of CLIL methods by foreign language teachers in the UK. Coyle and Meyer (2020) introduced the principles for developing a quality framework for deeper learning in CLIL; Banegas (2017) assessed teacher-developed materials, sources and activities for the CLIL classroom. All this indicates a positive experience of CLIL implementation with various contexts in the educational process.

At the university level, CLIL is closely related to the specifics of teaching students of various specialities in general and tourism in particular. A number of scientists have dealt with the issues of professional training of tourism students, such as: a reflective approach application in the process of professional training of tourism students (Fullagar and Wilson, 2012), a balanced approach to professional knowledge and practical skills formation of tourism students (Zagonari, 2009), development and use of the theory of transformative training of future specialists in the field of tourism (Walker and Ngara Manyamba, 2020), aspects of tourism and hospitality education and a dynamic philosophic practitioner education curriculum space framework (Dredge et al., 2012), the use of virtual platforms in the process of professional training of tourism students (Chiao et al., 2018), features of professional education in tourism organization in UK higher education institutions (Walmsley, 2012), the use of experimental forms and methods of teaching students in the field of tourism and hospitality (Schreck et al., 2020). Thus, these studies reflect different aspects of the tourism and hospitality field and allow educators to build the educational process at university level close to the professional realities of tourism specialists.

In the process of learning how to interact with people from various cultures, the tourism students master the multicultural competence. It is an integrative quality of the tourism students that includes a system of sufficient multicultural knowledge, skills, interests, needs, motives, values, experience, social norms and rules of behaviour, necessary for solving problems of everyday life in the course of positive interaction with representatives of different cultures (social groups, nationalities, races, religious denominations) (Goncharova, 2019). The specifics of tourism managers' activity are aimed primarily at meeting the needs of tourists in socio-cultural and tourist services. Therefore, the main form of this activity is foreign language communication, and the principal communication partner is a client of different linguistic and cultural communities. Consequently, a tourism specialist must not only speak one or more foreign languages but also get to know various foreign cultures. In the context of developing multicultural competence, CLIL can be considered as a means of boosting foreign language communication skills and knowledge of foreign cultures.

Despite the significant number of scientific achievements regarding professional training of tourism students, the issues of preparation of such students at university level using CLIL approach for developing the multicultural competence may need further research.

\section{Aim}

Thus, the purpose of the article is to prove the effectiveness of the CLIL use in the tourism students' multicultural competence development at the university level. The following tasks were outlined:

- to define the constituent elements (knowledge, skills and abilities) of the multicultural competence of the tourism students;

- to determine the pedagogical conditions of successful CLIL implementation;

- to develop recommendations for developing the multicultural competence on the base of CLIL;

- to define the specifics of implementing CLIL in the educational process of the tourism students.

The hypothesis of the study was to assume that the development of the tourism students' multicultural competence will be effective if the following pedagogical conditions are taken into account: 1) integration of the content of cultural training of students in the process of studying professional disciplines; 2) use of interactive methods and activities of learning in the educational process; 3) stimulation of independent work of students through the organization of Ukrainian and foreign internship. 


\section{Methods}

Research design

To achieve the goal, a mixed-method was chosen, which implied the use of quantitative and qualitative research methods. The quantitative method was used to process the test results of the tourism students and determine the statistical significance of the results obtained during the experiment, the qualitative method was applied to analyse and interpret the results.

\section{Participants}

In order to test the methodology, a pedagogical experiment was prepared and conducted, which took place within the educational process of V. I. Vernadsky Taurida National University in Ukraine. A total of 25 tourism students took part in the experimental study in 2020-2021 academic year. To carry out a pedagogical experiment, two groups were formed: control (CG) and experimental (EG). The total number of students in EG was 13, the CG included 12 students.

\section{Ethical issue}

The study was conducted in accordance with ethical considerations. All students were informed about the purpose of the study. Everyone could refuse to participate in the experiment or stop participating in it at any time.

\section{Instruments and Procedure}

In the study, there were three stages.

At the first, initial stage of the experiment, two groups (experimental and control) of tourism students were formed randomly. The diagnostics of the levels of the multicultural competence development of the tourism students on the base of a pre-test (the maximum score was 100) was carried out, the strategy of pedagogical research was determined, its conceptual apparatus was specified, the tourism students were prepared to participate in the study.

The levels of multicultural competence based on the application of CLIL were assessed according to outlined professional knowledge, skills and abilities of the tourism students grouped in the following areas: Subject, Cognitive, Communication (sub-areas: "Verbal means", "Non-verbal means", "Stereotypes", "Strategies" and "Cross-cultural conflict"), Culture and Personal Areas, that are presented in Table 1. The outlined areas serve as the main criteria of the formation of multicultural competence.

Table 1. The constituent elements of multicultural competence of the tourism students

\begin{tabular}{|c|c|}
\hline Knowledge & Skills and Abilities \\
\hline \multicolumn{2}{|c|}{ Subject Area } \\
\hline $\begin{array}{l}\text { about specifics of different subjects; professional } \\
\text { subjects' topics; foreign language }\end{array}$ & $\begin{array}{l}\text { to apply information of different professional } \\
\text { subjects and their topics; to use foreign language } \\
\text { knowledge properly; }\end{array}$ \\
\hline \multicolumn{2}{|c|}{ Cognitive Area } \\
\hline $\begin{array}{l}\text { about critical thinking; problem-solving; } \\
\text { planning; teamworking }\end{array}$ & $\begin{array}{l}\text { to solve problems; to use thinking operations } \\
\text { (analysis, synthesis, evaluation, comparison, } \\
\text { classification); to plan; to enhance teamworking }\end{array}$ \\
\hline \multicolumn{2}{|c|}{ Communication Area } \\
\hline \multicolumn{2}{|c|}{ Sub-area of verbal means of cross-cultural communication } \\
\hline $\begin{array}{l}\text { about the rules and characteristics of verbal } \\
\text { communication, typical; specifics of human } \\
\text { behaviour of verbal communication }\end{array}$ & $\begin{array}{l}\text { to interact effectively with representatives of } \\
\text { different cultures (contact and distant cultures) } \\
\text { using verbal communication }\end{array}$ \\
\hline \multicolumn{2}{|c|}{ Sub-area of non-verbal means of cross-cultural communication } \\
\hline $\begin{array}{l}\text { about the rules and characteristics of non-verbal } \\
\text { communication; specifics of human behaviour } \\
\text { and non-verbal communication in different } \\
\text { cultures and social groups (contact and distant } \\
\text { cultures) }\end{array}$ & $\begin{array}{l}\text { to interact effectively with representatives of } \\
\text { different cultures (contact and distant cultures) } \\
\text { using non-verbal communication }\end{array}$ \\
\hline \multicolumn{2}{|c|}{ Sub-area of stereotypes } \\
\hline $\begin{array}{l}\text { about the concept "stereotype"; mechanisms of } \\
\text { stereotype formation; features, functions and } \\
\text { types of stereotypes; the role of stereotypes in } \\
\text { forming intercultural communication; managing } \\
\text { of stereotypes }\end{array}$ & $\begin{array}{l}\text { to generalise the social experience; to classify } \\
\text { information according to particular models in } \\
\text { communication; to oppose "we - they"; to apply the } \\
\text { knowledge about stereotypes in intercultural } \\
\text { communication to adapt in the society }\end{array}$ \\
\hline
\end{tabular}




\section{Sub-area of strategies}

about the communicative strategies; the roles of to apply the communicative strategies

the communicative strategies in the cross-

cultural communication

\section{Sub-area of cross-cultural conflict}

about the essence of conflict; the stages of 1 to find consensus in the conflict; to use the development of the conflict, as well as the nature of cross-cultural conflict; the causes of crosscultural conflicts; the principles of resolving cross-cultural conflicts

\begin{tabular}{|l|l|}
\hline & Culture Area \\
\hline about specifics of various cultures & \multicolumn{1}{|c|}{ to apply information of different cultures } \\
\hline $\begin{array}{l}\text { Personal Area } \\
\text { about personal strengths and drawbacks; } ; \\
\text { personal background and culture }\end{array}$ & $\begin{array}{l}\text { to understand personal background and culture; to } \\
\text { be able to aware how others might perceive you; to } \\
\text { apply personal strengths and drawbacks; to be able } \\
\text { to self-reflect }\end{array}$ \\
\hline
\end{tabular}

The task of the second stage of the experimental learning was to provide CLIL in the educational process for developing the multicultural competence of tourism students. At this stage, the following steps were done:

1) integrating the content of different professional disciplines into the foreign language for specific purposes;

2) involving various interactive methods and activities (case method, role plays, brainstorming, round table, project method) in the educational process;

3) stimulation of independent work of students through the organization of Ukrainian and foreign internship.

At the third stage, a post-test was suggested and the results of the experiment were processed.

Data Analysis

The process of data analysis involved three stages. Initially, a pre-test was offered to the tourism students to define the level of their multicultural competence. Three levels were defined: high, average and low. After the experimental learning, a post-test was suggested. The results of two tests were evaluated and compared using the Q-criterion of Rosenbaum.

\section{Results}

In order to identify the effectiveness of the educational process focused on the development of multicultural competence with the CLIL use, we outlined the levels of multicultural competence. The Low Level of multicultural competence (60-74 scores) means that a tourism student has limited knowledge of the cultural potential of different countries and makes serious errors in the process of cross-cultural communication. The Average Level of multicultural competence (75-94 scores) shows that a tourism student is quite knowledgeable of the cultural potential of different countries and in general uses it correctly in the process of cross-cultural communication applying appropriate skills and abilities. The High Level of multicultural competence (95-100 scores) indicates that a tourism student has good knowledge of the cultural potential of different countries and uses it correctly in the process of cross-cultural communication applying appropriate skills and abilities.

Tables 2 and 3 present the results of diagnostics of the levels of multicultural competence of the tourism students at the beginning and the end of the experiment, respectively due to the use of CLIL in the process of their professional training.

Table 2. The levels of multicultural competence of the tourism students in the pre-test

\begin{tabular}{|l|c|c|c|c|}
\hline \multirow{2}{*}{ Level } & \multicolumn{2}{|c|}{ EG } & \multicolumn{2}{c|}{ CG } \\
\cline { 2 - 5 } & $\begin{array}{c}\text { Number of } \\
\text { students }\end{array}$ & \%umber of & students & \\
\hline High & 2 & 15.38 & 1 & 8.3 \\
\hline Average & 5 & 38.46 & 5 & 41.7 \\
\hline Low & 6 & 46.15 & 6 & 50 \\
\hline
\end{tabular}


Table 3. The levels of multicultural competence of the tourism students in the post-test

\begin{tabular}{|l|c|c|c|c|}
\hline \multirow{2}{*}{ Level } & \multicolumn{2}{|c|}{ EG } & \multicolumn{2}{c|}{ CG } \\
\cline { 2 - 5 } & $\begin{array}{c}\text { Number of } \\
\text { students }\end{array}$ & $\%$ & $\begin{array}{c}\text { Number of } \\
\text { students }\end{array}$ & \% \\
\hline High & 7 & 54 & 1 & 8.3 \\
\hline Average & 5 & 38 & 6 & 50 \\
\hline Low & 1 & 8 & 5 & 41.7 \\
\hline
\end{tabular}

As a result of the experimental study, the number of EG students with a high level of the multicultural competence increased from $15.38 \%$ to $54 \%$, which is higher than the figure $(8.3 \%)$ for CG students at the end of the experiment; the number of students with an average level of the multicultural competence was the same in EG and increased in CG from $41.7 \%$ at the beginning to $50 \%$ at the end; the number of EG students with a low level of multicultural competence decreased significantly - from $46.15 \%$ according to the results of diagnosis at the initial stage of the experiment to $8 \%$ according to the results of the post-test, which is $33.7 \%$ more than the figure in CG students.

For defining which group of tourism students demonstrated a higher result of the development of multicultural competence, the Q-criterion of Rosenbaum was applied.

Two hypotheses were formulated:

$\mathrm{H}_{0}$ : the tourism students' level of multicultural competence in EG is not more significant than in CG as reported by the experimental results.

$\mathrm{H}_{1}$ : the tourism students' level of multicultural competence in EG is more significant than in CG as reported by the experimental results.

The scores in both groups (EG nd CG) were sorted in the descending order:

Table 4. The scores of the post-test in EG and CG in the descending order

\begin{tabular}{|c|c|c|c|c|c|c|c|}
\hline \multicolumn{4}{|c|}{ Experimental group } & \multicolumn{4}{|c|}{ Control group } \\
\hline Number & $\begin{array}{c}\text { Code of a } \\
\text { student }\end{array}$ & \multicolumn{2}{|l|}{$\begin{array}{c}\text { Scores of } \\
\text { students }\end{array}$} & Number & $\begin{array}{c}\text { Code of a } \\
\text { student }\end{array}$ & \multicolumn{2}{|c|}{$\begin{array}{l}\text { Scores of } \\
\text { students }\end{array}$} \\
\hline 1. & EGLM & 99 & & & & & \\
\hline 2. & EGNK & 99 & & & & & \\
\hline 3. & EGPS & 99 & & & & & \\
\hline 4. & EGTA & 98 & $\mathrm{~S}_{1}$ & & & & \\
\hline 5. & EGML & 97 & & & & & \\
\hline 6. & EGZD & 96 & & & & & \\
\hline 7. & EGKD & 96 & 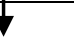 & & & & \\
\hline 8. & EGNS & 95 & & 1. & CGMM & 95 & \\
\hline 9. & EGNM & 94 & & 2. & CGNN & 94 & \\
\hline 10. & EGHR & 94 & & & & & \\
\hline 11. & EGOP & 93 & & & & & \\
\hline & & & & 3. & CGFD & 90 & \\
\hline & & & & 4. & CGLM & 82 & \\
\hline & & & & 5. & CGFN & 81 & \\
\hline & & & & 6. & CGDS & 80 & \\
\hline 12. & EGFT & 76 & & 7. & CGKH & 76 & \\
\hline 13. & EGKH & 74 & & 8. & CGGD & 74 & \\
\hline & & & & 9. & CGSA & 74 & \\
\hline & & & & 10. & CGMA & 73 & $\mathrm{~S}_{2}$ \\
\hline & & & & 11. & CGTR & 71 & \\
\hline & & & & 12. & CGJZ & 70 & \\
\hline
\end{tabular}

According to the results, the number of values in the first row is greater than the maximum value in the second row $\left(S_{1}=7\right)$; the number of values in the second row is less than the minimum value in the first row $\left(S_{2}=5\right)$.

Using the formula $Q_{e m p} .=\mathrm{S}_{1}+\mathrm{S}_{2}$, suggested by Rosenbaum and described in the book of 
Sidorenko (2004), $Q_{e m p}=7+5=12$.

The critical values of $Q$ were determined for $\mathrm{n}_{1}=13, \mathrm{n}_{2}=12$ :

$Q_{c r}=\left\{\begin{array}{c}6(\mathrm{p} \leq 0.05) \\ 9(\mathrm{p} \leq 0.01)\end{array}\right.$

The greater the discrepancy between the samples, the greater the value of $\mathrm{Q}$. The axis of significance is demonstrated in figure 1.

demonstrated in figure 1.

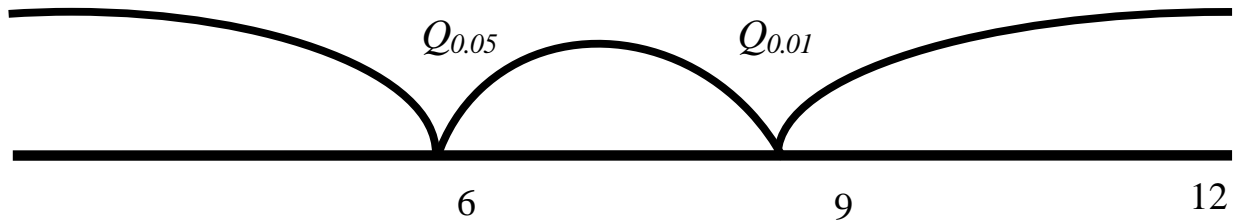

Fig. 1. The axis of significance

Thus, only the hypothesis $\mathrm{H}_{1}$ is accepted. This means that due to the CLIL approach the tourism students' level of multicultural competence in EG is more significant than in the CG.

\section{Discussion}

According to the results, it is evident that due to CLIL classes, the students' theoretical knowledge and practical skills in the field of tourism, the ability to interact with representatives of other countries and cultures, the ability to solve professional problems in the conditions of foreign language communication in the cross-cultural environment, have been increased.

The first condition of providing CLIL is the integration of the content of different professional disciplines into the foreign language for specific purposes. Synthesis of different professional disciplines allows the tourism students to understand the specifics of their profession in complex, shows how theoretical and practical professional knowledge are related, to create professional realities artificially and naturally through various communicative situations and immerse the students in the foreign language professional environment. Selected foreign language topics and authentic texts fill the professional content, serve as language samples, stimulate students to learn professional vocabulary, language structures. Thus, CLIL "provides a comprehensive framework that recognises the complex but necessary interrelationship between language and content for language development" (Thamrin, Kuntariati, 2015, p. 314).

The second condition of providing CLIL is focused on involving various interactive methods and activities (case-method, role plays, brainstorming, round table, project method) in the educational process. They help the students to practise communication in different ways. In line with it Coyle, Hood, and Marsh (2010) highlight that "much CLIL classroom practice involves the learners being active participants in developing their potential for acquiring knowledge and skills (education) through a process of inquiry (research) and by using complex cognitive processes and means for problem solving (innovation)" (pp. 3738). In other words, CLIL communication block "involves using language in the here and now to construct new knowledge and skills; offers direct opportunities to learn through language and to make meanings that matter; offers genuine opportunities to interact face to face and through the use of new technologies (e.g. internet, video-conferencing, international projects) (Coyle, Holmes, and King, 2009, p. 13)”. Additionally, teaching culture in foreign language communication for the professional purposes allows the tourism students to engage in a professional activity with great competence, to explore "the links between language and cultural identity", to examine "behaviours, attitudes and values", to "enrich the learners' understanding of their own culture and those of others" (Coyle, Holmes, and King, 2009, p. 13), to boost cross-cultural understanding.

Thus, practising foreign language communication in the field of tourism, the tourism students master a wide range of skills, in particular: to apply information of different professional subjects, cultures; to use foreign language knowledge; to solve problems in communicative situations; to use thinking operations (analysis, synthesis, evaluation, comparison, classification); to plan; to work in teams; to interact effectively with representatives of different cultures (contact and distant cultures) using verbal and non-verbal communication; to generalise the social experience; to classify information according to particular models in communication; to oppose "we - they"; to apply the knowledge about stereotypes in cross-cultural communication to adapt in the society; to apply the communicative strategies; to find consensus in the conflict; to use the principles of resolving cross-cultural conflicts; to apply information of different cultures; 
to understand personal background and culture; to be able to be aware how others might perceive you; to take into consideration personal strengths and drawbacks; to be able to self-reflect.

The third condition of providing CLIL involves stimulation of independent work of students through the organization of the Ukrainian and foreign internship in the process of which they are able to improve their knowledge and skills. It allows the tourism students to learn how a professional workplace is organised in the field of tourism; gain valuable real professional experience; to apply the received knowledge from the classroom; to increase the amount of responsibility performing intern duties and responsibilities; to build a professional network; to understand personal strengths and drawbacks in the professional environment; to increase personal motivation to continue professional studying.

Taking into account the conditions of successful providing CLIL in the educational process of the tourism students, the methodical recommendations can be outlined. Therefore, it is necessary

1) to plan and organise each lesson, based on the following areas: Subject Area, Communication Area, Cognition Area, Culture Area, Personal Area;

2) to clearly define goals, learning outcomes, methods, and criteria for assessment;

3 ) to regularly conduct a self-analysis of the classes;

4) to apply different types of assessment (including the alternative forms of assessment);

5) to develop and select high-quality materials, visual aids, and authentic texts for CLIL lessons;

6) to involve educators of different professional disciplines in the foreign language teaching.

The methodology of using CLIL of tourism students in the context of the development of their multicultural competence can be implemented through:

1) modular organisation of educational material;

2) modelling the communicative situations for tourism students;

3) selection of vocabulary and preparing exercises aimed at developing skills and abilities of tourism students;

4) use of professional authentic oral and written texts as a language sample;

5) development of language skills:

- reading: the ability to extract the general, key, and detailed information from professional texts, to evaluative and transform information from the texts;

- listening: the ability to extract key information, to understand opinions and explanations, suggestions, arguments, and counterarguments, to transform information into the necessary form;

- writing: the ability to use the grammar and vocabulary of a foreign language to write professional texts (e.g. business letters, tour programmes, advertising, etc.);

- speaking: the ability to communicate (ask for explanations, give instructions, recommendations, and advice in a communicative situation);

6) use of various material about different cultures, designing exercises that form knowledge about the cultural features of the language and nonverbal behaviour of native speakers;

7) choice of teaching methods and activities (case-method, role plays, brainstorming, round table, project method) that allow modelling foreign language communication between participants of the educational process;

9) development of an assessment system;

10) including the Ukrainian and foreign internship in the educational process.

Thus, due to CLIL it is possible to develop students' cross-cultural communication abilities; to prepare them for international communication; to create an opportunity to study thematic disciplines from different points of view and various perspectives; to study professional terminology in a foreign language; to improve the professional competences; to develop oral and written communication skills; to include various methods of classroom activities; to help to increase students' motivation to master the professional field.

\section{Limitations}

In our study, we focused on the opportunity of CLIL using for the development of the multicultural competence of the tourism students. However, our research had certain limitations which may affect the generalizability of its results. Firstly, the participants of our study were only the students of tourism speciality, which means that the findings may be generalised with caution. Secondly, the study was limited to Ukrainian tourism students. Thirdly, a bigger number of tourism students could have taken part in the research. Hence, similar researches can be conducted in other ESP contexts.

\section{Conclusions}

In conclusion, the knowledge of foreign languages is an integral part of the professional competence of a specialist in the tourism industry. CLIL as an educational approach is focused on the development of the 
multicultural competence of tourism students, which provides the ability and willingness of graduates to use a foreign language in the future professional communication. The CLIL use involves defining the purpose of learning; outlining the main knowledge, skills and abilities; selecting appropriate information from different subjects; structuring the content of foreign language learning; choosing methods, and means of learning, as well as implementing an assessment system of foreign language learning results. According to the study, it was evident that due to CLIL classes, the students' theoretical knowledge and practical skills in the field of tourism, the ability to interact with representatives of other countries and cultures, the ability to solve professional problems in the conditions of foreign language communication in the cross-cultural environment, had been increased. It was also proved that the development of the tourism students' multicultural competence was effective if the following pedagogical conditions were taken into account: 1) integration of the content of cultural training of students in the process of studying professional disciplines; 2) use of interactive methods and activities of learning in the educational process; 3 ) stimulation of independent work of students through the organization of Ukrainian and foreign internship.

References:

Aiello, J., Di Martino, E. \& Di Sabato, B. (2017).Preparing teachers in Italy for CLIL: reflections on assessment, language proficiency and willingness to communicate.International Journal of Bilingual Education and Bilingualism, 20 (1),69-83. doi:10.1080/13670050.2015.1041873

Aguilar, M. \& Muñoz, C. (2014). The effect of proficiency on CLIL benefits in Engineering students in Spain. International Journal of Applied Linguistics, 24, 1-18. doi:10.1111/ijal.12006

Banegas, D. L. (2017).Teacher-developed materials for CLIL: frameworks, sources, and activities. Asian EFL Journal, 19(3), 31-48. https://www.elejournals.com/asian-efl-journal/the-asian-efl-journal-quarterly-september-2017/

Banegas, D. L., \& del Pozo Beamud, M. (2020). Content and Language Integrated Learning: A Duoethnographic Study about CLIL Pre-Service Teacher Education in Argentina and Spain. RELC Journal. June 2020. doi:10.1177/0033688220930442

Bentley, K. (2010). The TKT Course CLIL Module.Cambridge:Cambridge University Press.

Burkart, T. (2018). Dialogic Introspection - a Method of Investigating Experience. Hu Arenas, 1, 167-190. doi:10.1007/s42087-018-0027-5

Cenoz, J. (2015).Content-based instruction and content and language integrated learning: the same or different? Language, Culture and Curriculum, 28(1), 8-24. doi:10.1080/07908318.2014.1000922.

Chiao, Huei-Ming, Chen, Yu-Li, Huang, Wei-Hsin. (2018). Examining the usability of an online virtual tour-guiding platform for cultural tourism education. Journal of Hospitality, Leisure, Sport \& Tourism Education, 23, 29-38. doi:10.1016/j.jhlste.2018.05.002

Coyle, D., Holmes, B., \& King, L. (2009). Towards an intergrated curriculum: CLIL National Statement and Guidelines.Languages Company.http://www.languagescompany.com/images/stories/docs/news/clil_national_statement_and_guidelines.pdf

Coyle, D., Hood, P., \& Marsh, D. (2010). Content and Language Integrated Learning.Cambridge:Cambridge University Press.

Coyle, D., Meyer, O. (2020).Quality assurance in CLIL higher education. In: Martínez Agudo, JD (ed.), Quality in TESOL and Teacher Education: from a Results Culture Towards a Quality Culture (pp.159-70). London: Routledge.

Dredge, D., Benckendorff, P., Day, M., Gross, Michael J., Walo, M., Weeks, P., \& Whitelaw, P. (2012). The philosophic practitioner and the curriculum space. Annals of Tourism Research, 39(4), 2154-2176. doi: 10.1016/j.annals.2012.07.017

Fullagar, S., Wilson, E. (2012). Critical Pedagogies: A Reflexive Approach to Knowledge Creation in Tourism and Hospitality Studies. Journal of Hospitality and Tourism Management, 19(1), 1-6. doi:10.1017/jht.2012.3

Goncharova, I.S. (2019). Formuvannya polikul'turnoyi kompetentnosti u maybutnikh menedzheriv turyzmu u vyshchykh navchal'nykh zakladakh [Formation of polycultural competence in future tourism managers in higher educational institutions]. Unpublished $\mathrm{PhD}$ thesis, State Institution "Luhansk Taras Shevchenko National University", Starobilsk, Ukraine.

Kao, Yu-Ting (2020). Understanding and addressing the challenges of teaching an online CLIL course: a teacher education study.International Journal of Bilingual Education and Bilingualism, 1-20. doi:10.1080/13670050.2020.1713723

Leshchenko, M., Lavrysh, Y., \& Halatsyn, K. (2018). The role of Content and Language Integrated Learning at Ukrainian and Polish Educational Systems: Challenges and Implication. Advanced Education, 5, 17-25. doi:10.20535/2410-8286.133409

Mann, S., Walsh, S. (2017). Reflective Practice in English Language Teaching: Research-Based Principles and Practices.London and New York:Routledge.

Morton, T. (2019).Teacher education in content-based language education. In Steve Walsh, Steve Mann (Eds.), The Routledge Handbook of English Language Teacher Education (pp.169-183). Routledge

McDougald, J. S. (2015).Teachers' attitudes, perceptions and experiences in CLIL: a look at content and language. Colombian Applied Linguistics Journal 17, 25-41. doi:10.14483/udistrital.jour.calj.2015.1.a02

Schreck, Cornelia M., Weilbach, J. Theron, Reitsma, Gerda M. (2020). Improving graduate attributes by implementing an experiential learning teaching approach: A case study in recreation education. Journal of Hospitality, Leisure, Sport \& Tourism Education, 26, 100214. doi: 10.1016/j.jhlste.2019.100214.

Sidorenko, E. V. (2004). Methods of mathematical processing in psychology. SPb.: OOO «Rech».

Thamrin, E., Kuntariati, U. (2015). What have the teachers learnt from CLIL? International Conference on Educational Research and Development: Trends and Challenges towards Asian Economic Community. Proceeding. Universitas Negeri Surabaya.

Walker, J., Ngara Manyamba, V. (2020). Towards an emotion-focused, discomfort-embracing transformative tourism education. Journal of Hospitality, Leisure, Sport \& Tourism Education, 26,100213. doi:10.1016/j.jhlste.2019.100213

Walmsley, A. (2012). Pathways into tourism higher education. Journal of Hospitality, Leisure, Sport \& Tourism Education, 11(2), 131-139. doi:10.1016/j.jhlste.2012.02.015

Zagonari, F. (2009). Balancing tourism education and training. International Journal of Hospitality Management, 28(1), 2-9. doi:10.1016/j.ijhm.2008.03.006 